\title{
THE SIEGE OF URŠU TEXT (CTH 7) AND OLD HITTITE HISTORIOGRAPHY
}

\author{
Gary Beckman \\ University of Michigan, Ann Arbor
}

Ever since its publication in hand copy by E. Weidner in $1916,{ }^{1} \mathrm{KBo} 1.11$ (CTH 7), a fragmentary Akkadian-language narrative of the Old Hittite wars in North Syria, has posed difficulties for the Hittitologist. Preserved is approximately the lower one-half of a single-columned tablet, so that the beginning and end of the composition are lacking. This circumstance naturally renders interpretation difficult, as does the poor quality of the single surviving manuscript. ${ }^{2}$ Although no new textual material has been added to CTH 7, more than a half-century has now passed since its primary edition (Güterbock 1938, 113-38). In view of advances in scholarship during this time, it is appropriate to reopen discussion of this particularly interesting example of Old Hittite historical writing. The absence of a reliable published English translation of $\mathrm{CTH} 7^{3}$ provides additional

R. Beal, B. R. Foster, H. G. Güterbock, H. A. Hoffner, and A. Unal all made helpful comments on a preliminary version of this paper. Abbreviations for Hittite text publications and Hittitological works are those given in The Hittite Dictionary of the Oriental Institute of the University of Chicago, Volume III (L-N), Fascicle 4, xv-xxviii. All other abbreviations are those of The Chicago Assyrian Dictionary, listed most recently in Volume 17 (S)), Part Il, ix-xxvi.

1. See also his corrections given in KUB 4 (1922) $50 \mathrm{a}$.

2. The scribe was inconsistent in his use of the Personenkeil and omitted signs in several lines: obv. $7^{\prime}, 8^{\prime}, 22^{\prime}, 31^{\prime}(?)$, $34^{\prime}$, rev. 14, 19, and 30 . He added extra signs in obv. 23(?), rev. 9 , and 12. An erasure in obv. $8^{\prime}$ indicates a correction, and erroneous or poorly-formed signs are found in obv. 12', 13', $14^{\prime}, 16^{\prime}, 19^{\prime}$, rev. $19,25(?)$, and $29(?)$.

3. The rendering of Luckenbill $(1920,207-9)$ is largely obsolete, and Gurney $(1954,178-79)$ is only partial. See also Smith (1942, 63-66), Goetze $(1963,128)$, and Gurney (1973, 245-46). justification for my efforts here, which consist of a new transliteration and translation, accompanied by a brief philological commentary and a discussion of some literary aspects of the text. ${ }^{4}$

KBo $1.11 \mathrm{obv!}$

$1^{\prime}$. (traces)

2'. mŠa-an-da $|t| e_{4}{ }^{!}-m a$ ub-lam $M e-[n] a-n i-\left[y a^{?}\right.$

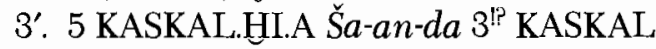
Me-na-ni-ya [ ]

4'. um-ma LUGAL-ma ${ }^{\mathrm{m}} \check{S} a-a n-d a$ a-lik

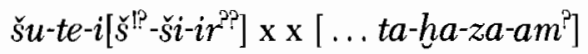

5'. ep-ša a-di ta-la-ku URU ${ }^{\mathrm{KI}} i$-hal-li-iq lu-ú na-a[s-ra-tu-nu $\left.u_{i}^{\text {? }} \mathrm{URU}^{\mathrm{KI}}\right]$

6'. i-hal-li-iq ù hi-ți-tum it-ta-na-ab-ši šum-ma ta-na-as-șa-r [a! hi-ti-tum?

7'. i-hal-li-iq-ma i-nu-ma [a-na] ta-ha-zi

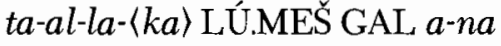
$p a-n[i-k u-n u]$

8'. ru-qi-iš ku-ul-li-ma (erasure) UR.GI 7 a-na

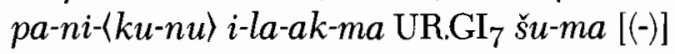

9'. ma-an-nu i-mar-šu um-ma šu-nu-ma ni-na-șa-[ar']-ma ù hi-ți-tam nu-hal-[la-aq]

10'. um-ma LUGAL-ma $i$-nu-ma URU $\mathrm{UI}^{\mathrm{KI}}$ i-hal-li-qú hi-ț-tum in-ne-ep-pu-uš a $[r-n u] m$

11'. in-ne-ep-pu-uš um-ma šu-nu-ma a-na 8-šu ta-ha-za-am ni-ip-pu-uš-ma

12'. URU ${ }^{\mathrm{KI}}$ i-hal-li-iq ù hi-ti-tam ${ }^{15}$ nu-hal-la-aq LUGAL ú-dam-mi-iq

4. Cf. the German treatment by Kempinski (1983, 33-41) and the recent discussion by Marazzi (1986, 25-44).

5. Text: -tim. 
13'. GIŠGUDSI.DILI $i s ̌-t e-e b-r u$ LUGAL $i-t e-z i-i z$

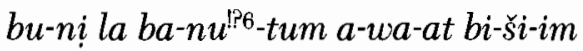

14'. it-ta-na-ba-lu ${ }^{17}$-nim ${ }^{\mathrm{d}} \mathrm{IM}$ li-ir-hi-iș-ku-nu-ti um-ma LUGAL-ma la ta-aš-ta-na-sú-ka

15'. GIŠGUD.SI.DILI LÚ.MEŠ Hur-ri ep-ša-ma li-iš-ša-ki-in ḩur-ša-an ep-ša-ma šu-uk-na

16'. GIšGUD.SI.DILI GAL $i s ̌-t u$ HUUR.SAG

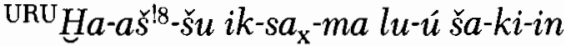
$e p-r a^{1 ? 9}-a[m]$

17'. ša-pa-ka șa-ab-ta i-nu-ma tu-q[a]-at-ta-a ma-am-ma qa-qa-ar-šu li-iș-bat

18'. ta-ha-za-am li-pu-šu ù ša šu-nu-ti te $e_{4}-e m-\check{s} u-n u$ i-pa-ar-ri-ir

19'. um-ma ̌̌a-ri-wa-an-da-ma ku-uș-șú ka-aš-du-nim an-nu-ut-tum ep ${ }^{110}$-ra-am li-iš-ta-pa-ku

20'. ù an-nu-ut-tum li-iš-ta-as-sú-ku LUGAL $u d-d a-m i-i q$

21'. LUGAL ' '̌́a-an-da i-na ${ }^{\mathrm{URU}} L u-h u-u z-z a-a n-d i-y a$ iș-sí ù ARAD LÚ URU Kar-ka-mi-is

22'. LUGAL iš-ta-na-a-al-šu KUR-tum ki $i-[d] a ́ b-b u-u b$ um-ma šu-úl-ma) šum-ma ${ }^{\mathrm{URU}} U r$-š $u^{\mathrm{KI}} i$-hal-li-iq

23'. ARAD i-na qa-ti-ni i-ma-qú-ut i-na-an-na ARAD.MEŠ $\check{s} u\{-n u\}$ ? $i-n a$ HUUR.SAG $a \check{s}-b u$ i-na-țà-lu

24'. um-ma LUGAL-ma te-eš-te-ne-em-me-e eš-te-ni-me a-lik du-bu-ub-šu-nu-ši

25'. šum-ma at-ta ù šum-ma at-ta lu-ú em-qé-et ù dam-qi-iš ú-e-ra

26'. i-na ${ }^{\mathrm{URU}} \mathrm{Ha}$ a-at-ti bi-iš-tum ú-ul i-ba-aš-ši $i$ na-an-na ${ }^{\mathrm{m}} \mathrm{Nu}$-un-nu ù Ku-li-a-it

27'. bi-iš-tam i-pu-šu i-na-an-na ša LÚ URU Kar-ka-mi-is ${ }^{\mathrm{KI}} i-p u$-šu ta-mu-ra

28'. ma-am-ma li-ih-su ${ }_{\mathrm{x}}-$ ús $^{\mathrm{m}}$ I-ri-ya-ya i-la-kam-ma ú-sa-ar-ra-ar

6. Text: $-t u$ -

7. Text: $-u r$ -

8. Text: $-n i-$

9. Text: -kum ${ }^{2}$ -

10. Text: $u r-$
29'. AN.ZA.GÀR $u$ GIŠGUDSI.DILI $n u-u b$ - $b a$-lam AN.ZA.GÀR $u$ GIŠGUDSI.DILI $u-u l u-b a-l u-n i$

30'. ù a-wa-ti i-na-țà-al-ma ul-li-ša-a|m] ú-bal i-na-an-na ku-uššsi-da-šu

31'. ù ki-a-am qi-bi-šu at-tu-nu ni广-a $\left.{ }^{\text {?- }}\right\rangle t i$ tu-sa-ra-ra ù ni-i-nu LUGAL $n u-s a_{\mathrm{x}}-r a-a r$

32'. i-na URU Ha-at-ti AN.ZA.GÀR $\grave{u}$ GIŠGUD.SI.DILI $\hat{u}$-ul $\boldsymbol{i}$-ba-aš-ši $a \check{s}$-šum an-nu-ú

33'. qé-er-bu ni-ri-iš

34'. $\langle u m-m a\rangle$ LUGAL $\langle-m a\rangle$ a-wa-at a-bi-ya a-wa-at a-bi a-bi-ya e-te-zi-ib x [...]

35'. 1-en LÚ-lum GAL i-la-ak ù ÉRIN.MEŠ $i$-sú-um i-la-ak $i$-na x [ ...]

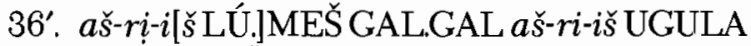
LÚ.MEŠ GIŠ̀'TUKUL $u-u l i z-z[a-z u \ldots]$

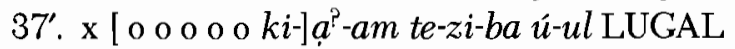
$a-n a t e_{4}-m i-s ̌ u[\ldots]$

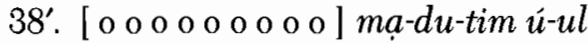
$a-t a-a z-z i-i\left[z^{2} \ldots\right]$

39'. [ o o o o o o o o ma']-du-tum i-qa-ab-bu a-na $i-\mathrm{x}[\ldots]$

40'. [ o o o o o o o o o o ] $\mathrm{x}-n u$ be-el né-me-qi $k i-m[a, \ldots]$

41'. [ o o o o o o $i$-qa-ab ] ]-bi a-na mi-nim la ga-aš-ma-x $[\ldots]$

$42^{\prime}$. [ [ o mi-nim ma-ta-t[e...]

43'. [ o o o o o o o o o o o a]d-di-na-šu [ ...]

rev!

1. $[000000000-z] a^{\text {P- }}-z i-i k-k i \times[\ldots]$

2. [o o o o o o o o o -r]i-madu-[..] ]

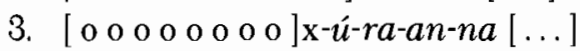

4. iš-pur-ma a-lik an-na am-ra-ni $k i-n a(-) a(-)\left[\begin{array}{lll}0 & 0 & 0\end{array}\right] \times \mathrm{x} \times[\ldots]$

5. sa-ar-ra ki ib-ši 30 GIŠGIGIR.HLI.A ša ${ }^{\mathrm{URU}} \mathrm{H} u-r u-u h-[h i-i] s$

6. ša a-na $\mathrm{URU}_{A}$-ši-hi i-ru-bu iṣ-ba-tu-ma a-na ${ }^{\mathrm{URU}} \mathrm{H} u-r u-u h-h i$-[iš $\left.u b-l u\right]$

7. um-ma Ku-li-e-et-ma DUMU.MEŠ DUMU ${ }^{\mathrm{d} I M}$ aš-šum šar-ru-tim im-ta-ha-ṣu

8. [at-t]a mi-nam ta-sa-ah-hu-ur ù ú-ma ša $a-n a$ pa-ni LUGAL $t u-u b-l a \mid m]$ 
9. $[u m-m] a \check{s} u\{-n u\}-m a \check{s} u-n u$ na-ak-ru ù a-na-ku na-ak-ra-ku-ma

10. $[\mathrm{m} \check{S}] a-a n-d a ~ t e_{4}-m a-a m$ ub-lam um-ma LUGAL-ma a-na mi-nim ta-ha-za la te-pu-uš

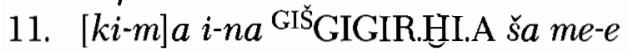
ta-az-za-az a-na me-ma-an ta-tu-ur-ma

12. $\mid t] e^{\text {?? }}-r i-i b\{-k a\}$ šum-ma-an a-na pa-ni-šu ta-ak-mi-is lu-ú-ma-an ta-du-uk-šu

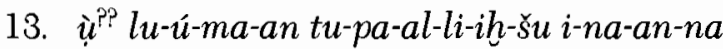
ku-la-ú-tam te-pu-uš

14. DUMU.MEŠ La-ri-ya mLa-ri-ya-aš(-ša) huu-u-uš-ki-wa-an-te-eš $z a-m a-r a \mathrm{~d} Z a-b a_{4}-b a_{4}$ $i z-m u-r u$

15. KISLAH la-ah-ni-it še-ḩu-we(PI)-en UR.TUR kur-zi-wa-ni-eš GUD.SAG KISLAH

16. ub-lu-nim la și-la it-ba-lu pí-la-qa ub-lu-ni GI.HI.A it-ba-lu ki-ra-as-sà

17. $u b$-lu-nim SAG.GUL.GIŠ? it-ba-lu ku-li-e-eš-šar MU.IM.MA ${ }^{\mathrm{m}}$ Tu-ut-ha-li-ya

18. i-pu-uš i-na-an-na at-ta te-pu-uš ku-la-ú-tam

19. um-ma LUGAL-ma a-lik ša-al-šu-nu〈-ti〉 i-nu-ma a-na ${ }^{\mathrm{URU} U} U r-s ̌ i ~ t a-a l-l a-k a$ ABULLA ta-ša!? $-r a-p a$

20. ta-h̆a-za-a te-ep-pu-ša um-ma šu-nu-ma a-na 8-šu ta-ha-za-am ni-ip-pu-uš-ma

21. [t] $e_{4}$-em-šu-nu nu-pár-ra-ad-ma $\mathrm{URU}^{\mathrm{KI}}$-lam nu-hal-la-aq um-ma LUGAL-ma da-mi-iq

22. a-di a-la mi-im-ma ú-ul i-pu-šu ARAD.MEŠ LUGAL ma-du-tim ú-ma-ah-hni-șú

23. ù ma-du-tum i-mu-tu LUGAL $u t-t a-k a_{4}$-ar um-ma LUGAL-ma KASKAL.HII.A uṣ-ra

24. $\check{a} a a-n a \mathrm{URU}^{\mathrm{KI}} i$-ru-bu ša $i \check{s}$-tu URU $\mathrm{UI}^{\mathrm{KI}}$ ú-uṣ-șú-ú uș-ra bi-ri-iš $a-n a{ }^{\text {LÚKÚR } l a}$ ú-uṣ-șí

25. $a-n a{ }^{\mathrm{URU}} \mathrm{Za} a^{\text {? }}$-ru-a-ar $a-n a{ }^{\mathrm{URU}} \mathrm{H} a-l a-a b^{\mathrm{KI}}$ a-na ÉRIN.MEŠ Hur-ri ù a-na Zu-up-pa

26. um-ma šu-nu-ma na-aṣ-ra-nu 80 GIŠGIGIR.HI.A 8 ÉRIN.MEŠ URU ${ }^{\mathrm{KI}}$-lam $l a-a-m i$ Š̀̀- $b i$ LUGAL

27. la i-na-ak-ku-ud a-na aš-ri-iš ba-aš-ba-ku ù ${ }^{L U} m u-u n-n a-a b$-tum iš-tu URU ${ }^{\mathrm{KI}}$

28. ú-și-im-ma um-ma šu-ú-ma ARAD LÚ ${ }^{\mathrm{URU}} \mathrm{H} a-l a-a b^{\mathrm{KI}} 5-s ̌ u i-r u-b a$
29. ARAD Zu-up-pa i-na URU $\mathrm{UI}_{-m a} a$-ši-ib LÚ.MEŚ URU Za $a^{\text {I- }}$-ru-a-ar i-ru-bu ú-uss-șút?

30. ARAD DUMU ${ }^{\mathrm{I}} \mathrm{IM}$ be-li it-ta-na-la-[k]am um-ma šu-ú-ma an-nu-úl-ti) KÙ.BABBAR TÚG.HI.A GUD.HI.A UDU.HI.A

31. ú-pa-ah-hni-ir a-na ÉRIN.MEŠ Hur-ri a-na-ad-di-in-ma šum-ma im-ta-ag-ru 7-šu id-dú-tam

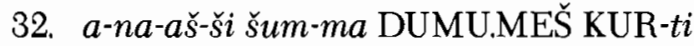
ú-ba-lam 2-šu a-na-aššš a-na ma-ḩar LUGẠL ${ }^{\text {KUR }}{ }^{\text {? URUP }} \mathbf{x}[\mathrm{o}] \mathrm{x}$

33. LUGAL $i$-te-zi-iz um-ma LUGAL-ma a-na a-wa-ti iš-te-it ta-ak-la-a-m[a ... ]

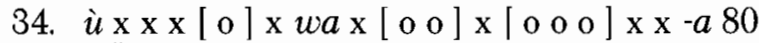
GIŠGIGIR.HI.A 8 ÉRIN [.MEŠ ... ]

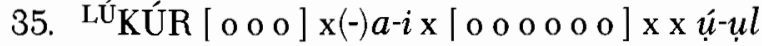
$t e^{?}-x[\ldots]$

36. $\mathrm{x}[\ldots]$

left edge.

tup-pís ša $\mathrm{x}\left[\begin{array}{lllll}0 & 0 & 0 & 0 & 0\end{array}\right]$

\section{Chariots of Water}

(obv! 1'-9')... Šanda brought a message: "Menani[ya?...] five columns of Šanda (and) three ${ }^{\text {? }}$ columns of ${ }^{?}$ Menaniya [..."] Thus said the king: "Šanda, go, march [on ${ }^{\text {? }}$... . ] give [battle!] While you are going, the city will come to ruin!be vigi[lant, lest ${ }^{\text {? }}$ the city] come to ruin and an offense occur. If you (pl.) are vigilan[t, the offensel will come to nought. When you go [into] battle, exhibit (your) nobles before [you] from afar! (But) a dog will run before (you . That dog [will...]-(but) who will see him?" They answered: "We will be vigilan[t], and the offense we will eradicate!"

(obv. 10'-18') Thus said the king: "When the city comes to ruin, an offense will have been committed, a s[in] brought about!" They answered: "We will give battle eightfold. The city will (indeed) come to ruin, but we will eradicate the offense." The king approved. (Then) they broke the battering-ram. The king was furious, (his) face (was) unpleasant-"They are always bringing me foul news! May the Storm-god wash you away!" 
The king continued: "You shall not continually slack off? Construct a battering-ram of Hurrian type and let it be put in place! Make siege-works and set (them) up! Cut a great battering-ram from the mountains of the city Haššu and let it be put in place! Begin to pile up earth! When you are finished let each take his place! Let them (the enemy) give battle, but their strategy will be foiled."

(obv. 19'-20') Thus said Šariwanda: "Winter is here-let some continually heap up earth, but let the others continually rest?" The king approved.

(obv. 21'-27') The king summoned Sanda to the city Luhuzzandiya, and the king interrogated him concerning the servant of the man of Carchemish (i.e., the king of Uršu"): "What is the country saying?" He answered: "If Uršu comes to ruin, the servant will fall into our hands. At the moment his ${ }^{13}$ servants are posted in the mountains and are keeping watch." Thus said the king: "Are you listening?!"-"I am listening" (he replied)"Go, speak to them: "Whether you or you, be clever and command well! In Hatti there is (ideally) no foul deed, but now Nunnu and Kuliat have committed a foul deed. Now you have witnessed what the man of Carchemish has done."

(obv. 28'-33') "Let each give it some thoughtIryaya will come and be deceitful (saying): 'We will bring a (siege)-tower and a battering-ram.' But they will not bring a (siege)-tower and a batteringram. He will examine the situation and transport (them) elsewhere. Now bring him in and speak to him thus: 'Will you (pl.) deceive us, so that we (in turn) will deceive the king? There is no (siege)tower or battering-ram in Hatti! (But) since this one is nearby, we will requisition? (it)."

(obv. 34'-37') (Thus said) the king: "Have I forsaken the word of my father (and) the word of my grandfather? [...] A single nobleman will go, and a small army will go in [...] In that place neither the noble[men] nor the overseer of the liegemen will be $\mathrm{i}[\mathrm{n}]$ position. $[\ldots]$ you (pl.) have [th]us? forsaken. I, the king, will not $[\ldots]$ to his report."

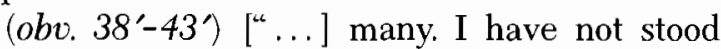
[...m]any will say: 'To $[\ldots]$..., Lord of Wisdom, lik[e...' ... say $] s^{\text {?: }}$ "Why ... [...] I brought? Why the land[s ... ] I gave to him [..."]

(rev! 1-9) ... he sent: "Go, look at this for me! Are they true? [...] Are they false?-How was it? They captured the thirty chariots of the city Huruhhiš which entered into the city Ašihi, [but they took them (back)] to Hurubh [iš]." Thus said Kuliet: "The sons of 'the Son of the Storm-god' are fighting one another over kingship. What are [yo]u seeking, and (what) have you brought today before the king?" He [ans]wered thus: "They are hostile, and I am also hostile!"

(rev. 10-21) Šanda brought a report. Thus said the king: "Why have you not given battle? Do you stand [as] on chariots of water, or have you perhaps (yourself) turned to water? Have you taken revenge? If you had fallen on your knees before him, you would certainly have killed him, or at least have frightened him! (But) now you have engaged (only) in hesitation! The sons of Lariya and Lariya (himself), while inactive, sang the song (of' the War-god) Zababa: "We have clogged? the threshing-floor with lahni! The puppies were wearing helmets?' They brought a fine ox of the threshing-floor, (but) they carried off (something that was) not a shield? ${ }^{\text {? }}$; they brought a spindle, (but) they carried off (mere) reeds; they brought a hair-clasp, (but) they carried off a wooden? club! Last year Tuthaliya engaged in hesitation-now you have engaged in hesitation!" The king continued: "Go, ask them: "When you go against Uršu, will you burn down the city gate? Will you give battle?" They answered: "Eightfold we will give battle! We will scare them out of their wits, and we will destroy the city!" The king replied: "That's good!"

(rev. 22-32) While they did nothing to the city, many servants of the king were hit, and many died. The king became angry and said: "Guard the roads-keep watch on those who would enter the city and those who would go out of the city! Let no (one) go over to the (other) enemies-to the city Zaruar, to the city Aleppo, to the Hurrian army, or to Zuppa!" They replied: "We will be on guard. Eighty chariots (and) eight armies encircle the city. May the heart of the king not be 
troubled. I am in place!" Then a fugitive came out of the city and said: "The servant of the man of Aleppo has entered five times; the servant of Zuppa is present in the city; the men of Zaruar go in and out; the servant of 'the Son of the Storm-god, my lord, goes back and forth, saying: 'I have gathered these (quantities of) silver, garments, oxen (and) sheep, and I will give (these) to the Hurrian troops. If they should agree, wages seven times I will deliver! If I bring 'sons of the land,' twice I will deliver.' "Before the king...

(rev. 33-36) The king became angry and spoke: "Trust (pl.) in a single word! [ . . ] . . eighty chariots (and) eight armies [...] the enemy [...]

(colophon, left edge) Tablet of [...]

\section{Philological Commentary ${ }^{11}$}

Numerous Hitticisms betray the native tongue of the author of $\mathrm{CTH} 7$, and several portions of the text (rev. 14-15, 17) are indeed in Hittite.12 It is my view that the present text is the translation of a lost Hittite original, ${ }^{13}$ made already in the

11. See also in general Güterbock (1938, 124-30).

12. Güterbock has already cited the unusual usages of alik (obv. 4', 24', rev. 4, 19), šumma ... šumma (obv. 25'), and awat ...ezēbu (obv, 34'). Starke $(1977,157$ n. 17) compares ša šunuti têmšu in obv. 18' with the common Old Hittite construction involving pleonasm of the independent and enclitic genitive pronouns, postulating an underlying *sumenzan... -šmiš in this instance. Note also the construal of ÉRIN.MEŠ in obv. $35^{\prime}$ as a singular, probably under the influence of the Hittite collective $t u z z i$ - (but of. $A H w 1072$ a for the possibility that ERIN.H1.A $=s a \bar{a} b u(m)$ is sometimes a grammatical singular). H. Hoffner has pointed out to me that the construction of aläkum with surrurum in obv. $28^{\prime}$ is modeled on the common phraseologic use of Hittite $u w a$ - with a second verb. (That is, the Akkadian is a rendering of Hittite "uizzi Iriyaš marše(s)zi.) See also my remarks below on obv. $17^{\prime}$. Note fi-

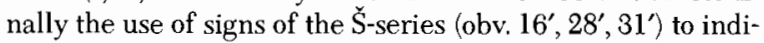
cate samekhs, a phenomenon familiar from later Boğazköy Akkadian (see Labat [1932, 35-36]).

13. Of course it is also possible that the piece was composed directly in Akkadian by a speaker of Hittite-cf. Kempinski $(1983,34)$. However, the fact that several other Akkadianlanguage historical texts from the Old Kingdom (CTH 4, CTH 6 , and CTH 19) are portions of bilinguals makes it more likely that a Hittite version also once existed for CTH 7. Although KBo 3.60, the "Menschenfressertext" (CTH 17-see Güterbock $[1938,104-13])$, may well deal with the same complex of events as $K B o 1.11$ (so Klengel [1992, 81 n. 218]), it differs
Old Kingdom, as shown both by the archaic script of the tablet ${ }^{14}$ and by a number of Mari-like features of the Akkadian. ${ }^{15}$ Compare here the Hittite and Akkadian versions of the Annals of Hattušili I (CTH 4), the ruler to whom $K B o 1.11$ is almost certainly also to be attributed. ${ }^{16}$

$o b v ! 3^{\prime}$ : For the emendation $3 !$ here, yielding a total of eight columns, cf. 8-š $u$ in obv. $11^{\prime}$ and rev. 20, as well as 8 ÉRIN.MEŠ in rev. 26. Of course, the eight columns might also be arrived at through an emendation $6^{!}$at the beginning of the line, or through the restoration of a unit in the break at its end. Cf. comment on rev. 28-30 below.

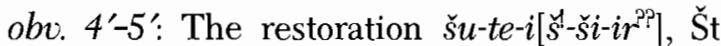
imperative, 2.m.sg., of ešerru, "to march on" (CAD E 358) fits the context well, but collation is needed.

For the restoration at the end of the line, $\mathrm{cf}$. obv. $11^{\prime}$, etc. Since talaku is 2.m.sg.subj., I have interpreted $e p$-ša as a singular ventive imperative epša $(m)$ rather than as plural epša with Güterbock $(1938,115)-c f$. comment below on obv. $25^{\prime}$.

$o b v .6$ ff:: While the king is certainly interested in capturing the besieged town, he is evidently also concerned lest it be totally destroyed by his forces. Throughout this text there is play on the several nuances of halāqum/hulluqum (CAD H 36-40).

completely in character and is unlikely to represent a portion of this postulated Hittite-language version of $C T H 7$.

14. See Neu (1983, x n. 7), who judges this text to be inscribed in Old Hittite "Duktus I." He also reports that inspection of a photograph shows that Weidner miscopied several URU-signs (obv. $5^{\prime}$ and elsewhere), whose shapes are actually compatible with an early date of inscription.

15. See below on obv. $25^{\prime}$ and $31^{\prime}$ and rev. 22.

16. There can be little doubt that the king in CTH 7 is either Hattušili I or Muršili I, the rulers under whom the initial Hittite expansion into North Syria was accomplished. Indeed, the Annals of Hattušili I mention campaigns in the land of Waršuwa/Uršu (Hitt. KBo 10.2 i 16-17 = Akk. KBo 10.1 obv. $7-9$ ), although it is uncertain if the events of our text are identical to those briefly touched on there-cf. Klengel $(1969,7-8$ and 1992, 81), Gurney (1973, 245-46) and Kempinski and Košak $(1982,109-10)$. See Güterbock $(1938,134)$ for strong arguments that the events referred to occurred before the reign of Muršili I. I see no reason to believe that the composition was not roughly contemporary with the incidents described. See also Klengel (1965, 36-37 with n. 21), and Goetze (1963, 128). 
$o b v .7^{\prime}:$ In this and the following line the terminative preposition ana is employed in place of the locative preposition ina. For this usage in Akkadian and Hittite texts from Boğazköy see Labat $(1932,100)$ and Neu $(1974,26)$.

obv. 8': The Sumerogram here must be read UR.GI ${ }_{7}$-see Güterbock (1938, 115 n. 14)-despite the representation of the second element with KU instead of the TÚG usual at Boğazköy. Since Gordon $(1958,72)$ demonstrates that UR. "KU" is normative in Kassite texts, perhaps the writing in our composition is due to Babylonian influence.

obv. 9': According to the copy and Güterbock $(1938,126)$, space is not sufficient to allow the restoration of the long sign AR here. As there can be no question but that a form of nașārum is intended, however, we might either choose Güterbock's suggested RÙ, which would present a grammatically incorrect form, or assume some partial writing of the correct AR, e.g., "ŠI- $\langle\mathrm{RI}\rangle$ ".

obv. 12': hi-ti-tim as it stands in the text is morphologically genitive singular, despite its function as the object of nuhallaq. I have corrected this error through emendation. Cf. CAD H 209-10 where this emendation is assumed without comment, and Marazzi $(1986,26)$.

obv. 13': For the emendation see CAD B 321. On the concentration of early references to GUD.SI.DILI in Syrian sources see Steinkeller (1987).

obv. 14': ta-aš-ta-na-ZU-ka here and li-iš-taAZ-ZU- $k u$ in obv. 20' are correctly-formed Gtn present/future and precative, respectively, of a root $\check{s} Z k$, which however, does not exist! Güterbock $(1938,126)$ suggests that they may be incorrect forms of šumsukum, "to give a bad name" (CAD M/I 322). That is, šumsukum > šussukum through assimilation, resulting in a pseudo-root “šsk. On the other hand, CAD N/II $20 \mathrm{~b}$ interprets these as irregular $\breve{~} \mathrm{t}$ forms from $n s k$, translating obv. 20' "some should heap up earth, and some should remove(?) it," although the general definition given for šutassukum is "to be rejected, canceled." Neither of these solutions is satisfactory, but comparison of the two contexts in which the difficult verb appears-one positive, the other neg- ative-leads us to the general idea of inactivity. $A H w 1206$, sub šaz/saku, "sich ausruhen" (hapax), suggests possible contamination from Hittite šešk-, "to sleep" (HW $\left.{ }^{1} 191\right)$. See also Marazzi (1986, 29).

obv. 15': The appearance of hur-ša-an without case ending is curious. Perhaps this arose due to misinterpretation of a Sumerogram HURSAG (i.e., [hursan]) in an earlier version of the text as a phonetic writing. Compare the Hittite plant name Ú hur-ša-an in KUB 37.1 obv. 20, which Köcher $(1952,54)$ plausibly explains as a rendering of Sumerian ÚHUR.SAG ${ }^{\text {SAR }}$. In any case, the term "mountain" is employed here metaphorically for earth piled up by the besiegers. CAD H 254 renders it "(siege) ramp."

obv. 17': For șabātum with infinitive as "to begin," see $A H w 1068 \mathrm{~b}$ and $C A D S S$ 21. However, I suspect that in fact we have here a calque on the normal usage of Hittite $e p$ - $\left(H W^{1} 41\right)$. Similarly qaqqaram șabātum is modeled on Hittite pedan $e p$ - (cf., e.g., $K B o 10.25$ vi $8^{\prime}$ and $I B o T 1.36$ i 9).

obv. 18': Starke (1977, $157 \mathrm{n}$. 17) points out that i-pa-ar-ri-ir here must be interpreted as an $\mathrm{N}$ stem ipparrir, contra $A H w 830 \mathrm{a}$ (6). Cf. also KUB 4.66 ii 5: te $e_{4}$-em KUR ip-pár-ru-ur.

obv. 22': For diverse opinions on the location of Uršu, see del Monte $(1978,475-76)$ and Groneberg $(1980,250)$. P. Matthiae has also voiced the possibility that Tell Touqan, a site near Ebla also excavated by his team, might be the ancient Uršu-see Matthiae (1979, 9 and 1983). The close connection of Ebla and Uršu was stressed already by Kupper (1949, 79-83) and Smith (1956, 3940). For summaries of our knowledge concerning Uršu, see Klengel (1965, 258-68; 1989, 265-67; and 1992, 74-77).

$o b v, 25$ ': Since lī emqet (for emqēta, a Mariism?) is $2 . \mathrm{m} . \mathrm{sg}$. of the stative precative, it is best to interpret $\hat{u}-e-r a$ with $A H w 1472 \mathrm{~b}$ as $w \bar{e} r a(m)$, 2.m.sg. ventive of the D-stem imperative, rather than as the plural imperative werrā, despite the preponderance of mimation in this text.

obv. 31': Instead of the emendation $n i-\langle a-\rangle t i$ one might, with Starke (1977, 120 n. 67), see another Mari-ism, né-ti. 
obv. 34': My emendation, which attributes the words of this and the following lines to the king, is necessary since "my father" and "father of my father" in this context can refer only to earlier monarchs. Güterbock $(1938,119)$ renders ētezib as "hat ... verlassen," but as $\mathrm{H}$. Hoffner has remarked to me, this text is consistent in distinguishing $i$-and $e$-vocalization of verbal prefixes, and we should therefore expect itezib for the third person. I also owe to Hoffner the interpretation of obv. $34^{\prime}$ as a rhetorical question.

obv. 36': Emend perhaps with Marazzi (1986, 34 with previous lit.) to UGULA LÚ.MEŠSIPA! but cf. Güterbock $(1938,127)$, and CAD A/2 455b. On LÚ GIŠTUKUL see Beal (1988a, 282) where our context is discussed. I believe that we indeed have here a reference to military personnel enjoying usufruct of land in return for their service. My translation "liegemen" is of course anachronistic and inadequate, but it is employed for want of a better short English equivalent for the more judicious German "Arbeits-/Kriegsdienstpflichtiger."

obv. 40: Due to the fragmentary context, it is uncertain if bel nēmeqi here has its usual function as an epithet of Ea-see CAD N/II 161.

rev! 8: For sahārum as "suchen," see $A H w$ $1006 \mathrm{a}$, where this passage is cited.

rev. 11: For the reading and restoration $[k i-m] a$, see Kempinski $(1983,39)$. On the problem of the relationship of Hittite kuleššr and secondary ${ }^{17}$ Akkadian kulaūtum, see Otten and von Soden 1968: 24. Beal (1988b) discusses the Anatolian word $k u l i$-and its derivatives. The semantic field covered by these words seems to be that of "inertia, idleness; peace."

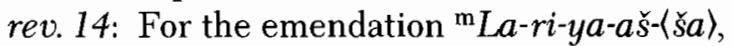
see Kempinski $(1983,40)$.

rev. 15: As opposed to Güterbock $(1938,129)$, I see this and the following line and one-half as the text of the "war song." ${ }^{8} \check{s} e-h u$-PI-en is probably a Hittite preterite, 1.pl. For the assumption

17. Marazzi $(1986,35)$ unconvincingly maintains that these words are independent of one another.

18. For another song in a military context, see $K B o 3.40$ rev. $13^{\prime}-15^{\prime}$ (CTH 16), recently edited in Soysal $(1987,177,181)$. that PI as a bilabial here retains its indifference to vowel quality, see Kempinski $(1983,40-41)$ and cf. Otten and Souček (1969, 47 and 78-79). See also Laroche $(1978,750-51)$. For the fuller form of the first person plural verbal ending, cf. haššsuweni (ha-aš-šu-ú-e-ni) KBo 8.74++ ii 9 (Neu 1980, 221), and paršs=uwani (pár-šu-wa-ni) KBo 17.4 iii 16 (Neu 1980, 16; cum. line ct. iii 47).

Despite the $e$-vowel in the first syllable, I understand the verb as a form of $\breve{s} a h$. In connection with lahni-, a potable liquid (see CHD III 12), it is probably to be rendered "clog"-see Güterbock (1964, 272 n. 20), and cf. Puhvel (1979, 300-301).

UR.TUR kurziwaneš is apparently a Sumerographic noun modified by a Hittite adjective. I interpret the expression as a plural, although the Sumerogram carries no MEŠ or HI.A, because the preceding and following subjects are plural. In addition, kurziwaneš is best interpreted orthographically as nominative plural. This word, if correctly read, is a hapax, but it may be related to the adjective gurzipant, "provided with a helmet?"19

rev. 15-17: The text returns to Akkadian here, but the interpretation of the sequential actions described nonetheless remains problematic. As Güterbock $(1938,129)$ recognized, we are confronted with three pairs of bringing $(u b l \bar{u} n i(m))$ and carrying off $(i t b a l \bar{u}) \cdot{ }^{20}$ In each case we have

19. For gurzipant, see von Brandenstein (1943, 63 n. 1). The underlying (Hurrian?) gurzip attested in various shapes at Mari, Amarna, Boğazköy, and especially Nuzi (see CAD G 139-40) |sub gurpisu], AHw 929b [sub qurpi(s)su(m)], and Laroche $(1978 \mathrm{~b}, 155)$ [sub gurbisi $i])$ denotes a piece of armor protecting the head-see Kendall (1981, 202-6). For the Boğazköy material, see Kümmel $(1965,106)$. Note that gur-zi-ip $p^{\text {!? }}$ ši-a-an [ (KBo 13.230:2) confirms that the item was worn on the head; hence my translation "provided with a helmet." H. Hoffner (private communication), while expressing uncertainty as to the equivalence of gurzipant and kurziwani-, points to the leather(?) protective collars worn by Hittite charioteers in Egyptian reliefs (see Yadin [1963, 196-97]) and tentatively renders UR.TUR kurziwaneš as "puppies wearing (leather) collars."

20. $C A D \mathrm{~K} 407$ incorrectly segments this passage: "They took away the.... and brought (instead) a spindle, they took away the arrows and brought (instead) a hair clasp." See also Archi $(1977,33)$, who deals only with the second two pairs: "Portarono un fuso e tolsero le frecce, portarono uno spillone e tolsero il chiavistello." 
the replacement of the first item by the second, in an apparent parody of the Hittite ritual for the conferring of martial qualities ${ }^{21}$-see below.

My reading la silla near the beginning of rev. 16 represents a rather desperate attempt to provide some interpretation for a sequence of signs Güterbock found "sinnlos." I tentatively propose to see here a substantivization of the secondary meaning of sillum, "protection, aegis" (CAD S 189-92), with the sense of "screen, shield." In view of the theme of futility expressed by this song, I understand GI here not as "arrow," but as "(mere) reed."

For the reading of SAG.GUL.GIŠ as sankullum, "club", see already Güterbock (1938, 129 with n. 5) and more recently Marazzi $(1986,36)$. Note that the present line is cited under this Akkadian lemma by $A H w$ 1023a.

Although in the Annals of Hattušili I (CTH 4) the Sumerogram MU.IM.MA in the Hittite version (KBo 10.2 i 15 and 22) corresponds to $a$-na ba-la$a t$, "the next year," in the Akkadian (KBo $10.1 \mathrm{obv}$. 6 and 10, respectively), this certainly represents an error on the part of the author of this text, or more likely, on that of the scribe of the thirteenthcentury tablet $K B O$ 10.2. Note that this usage of MU.IM.MA is not found in any of the other manuscripts of CTH 4. The only additional copy to preserve a relevant portion of the text is $K B o 10.3$, which has MU-an-n[i]-m[a] in line 15' (dupl. of KBo 10.2 i 15). Even KBo 10.2 ii 11 shows MU.KAM-an-ni-ma.

That is, MU.IM.MA at Boğazköy does not generally stand for ana balät, as the reader who consults CAD B 51 might conclude. The passages cited there-in addition to those of CTH 4-include only our passage and KUB 3.125:3 (Hagenbüchner 1989, 360), which is too fragmentary for interpretation. In the present text, both the preterite verb $i$-pu-uš and the context indicate that MU.IM.MA must stand for its usual Akkadian equivalent $\check{s} a d d a g d a$, "in the previous year"

21. See Güterbock $(1938,133)$ and more generally Hoffner (1966).
(CAD Š/L 39). Cf. Kempinski and Košak (1982, 110 n. 6)..$^{22}$

rev. 21: tēmšunu nuparrad=ma, lit. "we will frighten their sense(s)"-cf. $A H w 827 \mathrm{~b}$.

rev. 22: mimma ul epēšum might also be understood as "to achieve nothing"-for this view see Houwink ten Cate $(1984,73)$-but "to do nothing" seems even more contemptuous and in harmony with the tenor of the king's remarks. ${ }^{23}$

rev. 23: Marazzi 1986: 38-39 points out that uttakkar may be parsed only as a Dt present. However, rather than follow his efforts to accommodate the sense of the formation ("[in den Plänen] geändert werden") to the present context, I prefer to interpret the form as an error for the $\mathrm{D}$ perfect (uttakkir) and retain the translation "became angry."

rev. 24: CAD B 249 renders bi-ri-iš as an adverb, "to the other side," while $A H w$ 122a lists it under berîs, "hungrig"-see also von Soden (1968, 459), where doubt is expressed as to the very existence of biriš. Nonetheless, I have followed the $C A D$ since its understanding of the word better fits the present situation.

rev. 25 and 29: For the possible emendation Za'-ru-a-ar, see the bibliography collected sub Aruar in del Monte 1978: 41. Since Klengel (1965, $168 \mathrm{n}$. 83) reports that collation of the tablet allows this reading, and Dossin $(1939,109)$ demonstrates the close association of Zarwar ${ }^{\mathrm{KI}}$ with Haššm ${ }^{\mathrm{KI}}$ (cf. URU Ha-ă̌s̆šu in obv. 16' here) in the Mari texts-extending so far as a common monarch Anišhurbi-I have accepted this suggestion. ${ }^{24}$

22. Marazzi $(1986,36)$ reads kuleššar $=m u$ imma, "indeed in regard to me (T. practiced) hesitation," but this is unlikely. If the beginning of this sentence were entirely in Hittite we would expect some sort of conjunctive element also to be present. Furthermore the adverb MU.IM.MA stands here in contrast to the following inanna.

23. Given the other Mari-isms in this composition it is also possible that we have here the idiom alam epessum, "to conquer a city" (CAD E 203). The line should then be rendered "while they in no way captured the city."

24. Forlanini (1985, 54-55) makes the interesting suggestion that the toponyms Zaruar of the Mari and Boğazköy texts, Zalwar of Alalah, and the southern Zalpa(b) of Boğazköy all refer to the same city. 
rev. 26: For $l \bar{a} m i$ as a transitive stative see Marazzi (1986, 39).

rev. 28-30: I am indebted to B. R. Foster for the observation that the report of the fugitive mentions eight incidents in which the Hittite siege was penetrated. In view of the significance of the number eight in the present composition-see comment above on obv. 3 '-this eightfold failure is probably intended as humorous. See the following discussion of literary aspects.

Since the "Son of the Storm-god" is seemingly a designation of the leader of the Hurrians (cf. Güterbock [1938, 135], Klengel [1965, 264], and Wilhelm $[1982,29])$ his "servant" is probably the king of Uršu.

rev. 31-32: These lines recount the efforts of the local ruler to hire mercenary forces. For našûm as "to deliver payments due" see CAD N/ II 92-93. id-dú-tam is apparently, with Güterbock $(1938,125$ and 130), an aberrant form of idû, "hire, wages." It seems as if those hired locally during this crisis will be compensated at twice the usual rate, while other Hurrian mercenaries will receive seven times their normal pay.

\section{Literary Aspects}

As Güterbock (1938, 137-38) and Hoffner (1980, 299-300) have pointed out, this text is literary in character. In particular, the extensive attribution of speeches to the main actors, a device reminiscent of the writings of Herodotus and Thucydides, ${ }^{25}$ demonstrates conclusively that we are not dealing with a primary historical source, but rather with a conscious effort to understand and interpret the course of events, that is, with historiography.

The seventy-five or so preserved lines of the text treat the encirclement of the town of Uršu by the Hittite army-hence the modern title of the piece, "The Siege of Uršu." Within these lines the action advances but little. Instead we find a number of anecdotes centering on the activities

25. Cf. Cancik (1976, 138-39 and 174 n. 99). of particular Hittite officers, some of whom are attested in other Old Hittite sources. ${ }^{26}$ Such anecdotes are not unusual in early Hittite historiography, being used extensively in "The Testament of Hattušili I" (CTH 6), for example, and constituting the totality of "The Palace Chronicle" $(C T H$ $8-9)$. What is remarkable in $K B o 1.11$ is the sustained employment of this Old Hittite rhetorical mode towards a single goal. Even more striking is the presence in the anecdotes of a quality that many scholars have declined to recognize in cuneiform literature, namely humor. ${ }^{27}$

In our text the Hittite monarch is a longsuffering figure. Only indirectly commanding the siege from his base in Cilicia, he is forced to endure the ignominy of constant oversights and failures on the part of his subordinates. The king's rage at this course of events is expressed by means of withering sarcasm. Note his exclamation in rev. 10-13 upon learning of a delay. While Güterbock (1938, 132) judges these lines to be "ironic," I would go further, and despite the difficulties of recognizing in an ancient text so culturally specific a quality as humor, declare this passage funny. Similarly, in obv. $28^{\prime}-31^{\prime}$ the king effectively mocks the efforts of an officer by the name of Iryaya.

An eye for the humorous, or at least the ironic, indeed contributes to the understanding of three passages that have up to now remained cruxes: Early in the preserved portion of the obverse (lines $7^{\prime}-9^{\prime}$ ), the king exhorts his commanders: "When you go [intol battle, exhibit (your) nobles before [you] from afar! (But) a dog will run before 〈you〉. That dog [will ... ]-(but) who will see him?"

I believe that we have here a play on the Hittite idiom piran huwai-, "to run before" $\left(H W^{1} 78\right)$, used of the champions-divine ${ }^{28}$ and human ${ }^{29}$-and/or

26. See Güterbock $(1938,133-36)$.

27. See Foster (1974, 69-85) and the literature cited p. 69 n. 1, and p. 70 n. 4. M. Riemschneider $(1954,114-16)$ argues that all of the Hittite epic texts are "Schwänke," a view which is surely overstated.

28. The data in regard to deities are collected in del Monte (1986).

29. See Beal (1992, 513-18) for piran huwai- used of persons and also the nomen actoris piran huyatalla-, which he renders "leader." 
commanders of a military force ${ }^{30}$ On the other hand, it is a common observation that dogsconsidered by the Hittites along with swine as unclean $^{31}$-often accompany the movements of a military force. Thus the burden of the king's comparison seems to be that while his officers might have a high opinion of themselves due to their responsible position within the line of march, this position in itself is an empty form-even a dog may "run before" 32 an army-in the absence of performance justifying that honor. Such a deliberate confusion of semantic levels-of the commonplace and the metaphorical-as is at work in this passage is a typical instrument of humor.

Rev. 14-15, which contain the material left in Hittite by the translator, also seem to be humorous. I readily admit that the interpretation of the Hittite text of the war song is extremely uncertain, but it is clear that these soldiers are mocked by their leader for preferring the form to the substance of martial activity. In my understanding of the words provided by the king for the song, the audience is presented with both a ludicrously ineffective activity - the washing of the threshingfloor with a beverage-and with the doubly incongruous picture of young dogs decked out in armour. If both lines refer to Lariya and his sons,

30. A good example of both usages is found in $K B o 3.6$ ii 21-24:

21. ... numu apiyaya ${ }^{\mathrm{d} I S ̌ T A R ~ G A S ̌ A N-Y A ~ p i r a n ~}$

22. huwāiš nuza apiyaya LÚKÚR IŠTU NÍTE-YA tarahhun

23. LÚ-LUM-ma kuiš piran buiyanza ēšta nankan GIM-an keunun

24. LÚKÚR-maza piddāit

And at that time Šaušga, My Lady, ran before me, so that I on my own defeated the enemy in even that instance. And when I slew the man who was "running before" (them), the enemy fled.

31. See Alp $(1983,329)$. Cf. also the oracle questions $K U B$ 5.7 obv. $24-25$ b and $K U B 5.10+$ obv. 19-24.

32. Note that the majority of attestations of piran huwaiindicate simply spatial precedence in a parade or line of march, e.g., KUB 52.95 iv 1-3:

1. LÚGUDÚ LUGAL-i piran

2. hūwāi GAL MEŠEDI-ma EGIR-an

3. hūūāi

The "anointed priest" runs before the king, the chief of the bodyguard behind. we have a sharply critical comment on the quality of their efforts and on their pretence to military virtue, as well as perhaps a reference back to the dog imagery discussed earlier.

In rev. 15-18 the king continues berating Lariya and his offspring through a parody of the Hittite ritual for the conferring of martial qualities. As Hoffner $(1966,330-32)$ has demonstrated, ${ }^{33}$ the usual pattern of such a rite features the exchange of feminine attributes such as distaff and mirror for masculine military equipment. In our text either the replacement of feminine attributes-or of possessions emblematic of peacetime, in the case of the ox-went awry, resulting in the acquisition of an unsuitable shield, mere reeds, and a fragile club, or else the whole activity again served as a substitute, rather than as a preliminary, for actual battle. Parody may of course also be viewed as a form of humor.

One might well ask the purpose of such a humorous composition. In my opinion the basic function of all Hittite historiography was the justification of the office of kingship, as well as of its current incumbent, in the eyes of both gods and men. This might be accomplished in a positive manner-through the cataloging of royal achievements, as in the Annals, or through the demonstration of the smooth and equitable functioning of society, as in the "Hittite Laws" (CTH 291-92). But the purpose is equally well served by a negative approach in which other humans are shown to be inferior to the person of the monarch. That is, the rule of the Hittite king is justified in "The Siege of Uršu" by means of the favorable comparison of this wise ruler with his incompetent subordinates. It must be remembered that any internal threat to the position of the Hittite king could have arisen only within the ranks of those nobles depicted so negatively in this text.

In conclusion I should add that this extremely interesting "negative" stream within Hittite historiography did not ultimately prove productive. While, of course, historiographic texts of the Empire period present unfavorable pictures of vari-

33. See also Marazzi (1986, 37-38), whose interpretation of the use of the rite in this passage differs greatly from mine. 
ous individuals-of Mariya in the Huqqana treaty (CTH 42), ${ }^{34}$ and of Urhi-Tešub in the "Apology" of Hattušili III (CTH 81), for example-none of these compositions is structured around the contrast between the competent and virtuous king, and the incompetent and often untrustworthy others. Like what Houwink ten Cate $(1984,59)$ has called the "sacred lore literature," 35 in which the historical and the mythical are presented on a common level, "negative historiography" as represented by "The Siege of Uršu" and "The Palace Chronicle" seems not to have survived the Old Kingdom.

35. See also Cancik $(1976,59)$.

34. KBo 5.3 iii $53-58$.

References

Alp, S.

1983 Beiträge zur Erforschung des hethitischen Tempels. Ankara: Türk Tarih Kurumu.

Archi, A

1977 I poteri della dea Istar hurrita-ittita. Oriens Antiquus 16:297-311.

Beal, R.

1988a The GIŠTUKUL-institution in Second Millennium Hatti. AoF 15:269-305.

1988b Kule- and Related Words. OrNS 57:165-80.

1992 The Organization of the Hittite Military, THeth 20. Heidelberg: Winter.

Cancik, $\mathrm{H}$.

1976 Grundzüge der hethitischen und alttestamentlichen Geschichtsschreibung. Wiesbaden: Harrassowitz.

del Monte, G.

1976 Répertoire Geographique des Textes Cunéiformes. Band 6. Die Orts- und Gewässernamen der hethitischen Texte. Wiesbaden: Reichert.

1986 'E gli dei camminano davanti a me.' Egitto $e$ Vicino Oriente 9:59-70.

Dossin, G.

1939 Les archives économiques du palais de Mari. Syria 20:97-113.

Forlanini, M,

1985 Remarques géographiques sur les textes cappadocienes. Hethitica 6:45-67.

Foster, B. R.

1974 Humor in Cuneiform Literature. Journal of the Ancient Near Eastern Society 6:69-85.

Goetze, A.

1963 Warfare in Asia Minor. Iraq 25:124-30.

Gordon, E. I.

1958 Sumerian Animal Proverbs and Fables: 'Collection Five' (conclusion). JCS 12:43-75.

Groneberg, B.

1980 Répertoire Geographique des Textes Cunéiformes. Band 3. Die Orts- und Gewässernamen der altbabylonischen Zeit. Wiesbaden: Reichert
Gurney, O. R.

1954 The Hittites. Baltimore: Penguin.

1973 Anatolia c. 1600-1380 B.C. In Cambridge Ancient History, Third edition. Vol. II, Pt. 1, Ch. XV. Cambridge: Cambridge University.

Güterbock, H. G.

1938 Die historische Tradition bei Babyloniern und Hethitern bis 1200. Zweiter Teil: Hethiter. ZA 44:45-149.

1964 Review of A. Kammenhuber, Hippologia Hethitica. JAOS 84:267-73.

Hagenbüchner, A.

1989 Die Korrespondenz der Hethiter. 2. Teil. Die Briefe mit Transkription, Übersetzung und Kommentar, Texte der Hethiter 16. Heidelberg: Carl Winter.

Hoffner, H. A., Jr.

1966 Symbols for Masculinity and FemininityTheir Use in Ancient Near Eastern Sympathetic Magic Rituals. JBL 85:326-34.

1980 Histories and Historians of the Ancient Near East-the Hittites. OrNS 49:283-332.

Houwink Ten Cate, P. H. J.

1984 The History of Warfare according to Hittite Sources: The Annals of Hुattušiliš I (Part II). Anatolica 11:47-83.

Kempinski, A.

1983 Syrien und Palästina (Kanaan) in der letzten Phase der Mittelbronze IIB-Zeit (1650-1570 v. Chr.). Wiesbaden: Otto Harrassowitz. , and S. Košak

1982 CTH 13: The Extensive Annals of Hattušili I(?). Tel Aviv 9:87-116.

Kendall, T.

1981 Gurpisu ša aweli: The Helmets of the Warriors at Nuzi. In Studies on the Civilization and Culture of Nuzi and the Hurrians, ed. M. A. Morrison and D. I. Owen. Pp. 201-31. Winona Lake: Eisenbrauns.

Klengel, $\mathrm{H}$.

1965 Geschichte Syriens im 2. Jahrtausend v. u. Z. Band I: Nordsyrien. Berlin: Akademie. 
1969 Syrien in der hethitischen Historiographie. Klio 51:5-14.

1989 Syrischer Handel und die Texte aus Kültepe/ Kaniš. In Anatolia and the Near East. Studies in Honor of Tahsin Özgüc, ed. K. Emre et al. Pp. 263-68. Ankara: Türk Tarih Kurumu.

1992 Syria, 3000 to 300 B.C. Berlin: Akademie.

Köcher, F.

1952 Ein akkadischer medizinischer Schülertext aus Boğazköy. AfO 16:47-56.

Kümmel, H. M.

1967 Ersatzrituale für den hethitischen König, StBoT 3. Wiesbaden: Harrassowitz.

Kupper, J.-R.

1949 Uršu. RA 43:79-87.

Labat, R.

1932 Laccadien de Boghaz-köi. Bordeaux: Delmas. Laroche, E.

1978a Glossaire de la langue hourrite. Paris: Klincksieck.

1978b Problèmes de l'écriture cunéiforme hittite. Annali de Scuoli Normale Superiore di Pisa, Cl. di lettere e filosofia, Serie III, vol. VIII/ 3:739-53.

Luckenbill, D. D.

1920 Hittite Treaties and Letters. AJSL 37:161-211.

Marazzi, M.

1986 Beiträge zu den akkadischen Texten aus Boğazköy in althethitischer Zeit. Rome: Dipartimento di Studi Glottoantropologici, Università "la Sapienza"

Matthiae, P.

1979 Sondages à Tell Touqan (Syrie). Akkadica 14:6-10.

1983 Tell Tuqan bei Ebla. Antike Welt 14:40-50.

Neu, E.

1974 Der Anitta-Text, StBoT 18. Wiesbaden: Harrassowitz.

1980 Althethitische Ritualtexte in Umschrift, StBoT 25. Wiesbaden: Harrassowitz.

1983 Glossar zu den althethitischen Ritualtexten, StBoT 26. Wiesbaden: Harrassowitz.
Otten, H., and V. Souček

1969 Ein althethitisches Ritual für das Königspaar, StBoT 8. Wiesbaden: Harrassowitz. , and W. von Soden

1968 Das akkadisch-hethitische Vokabular KBo I $44+$ KBo XIII 1, StBoT 7. Wiesbaden: Harrassowitz.

Puhvel, J.

1979 Some Hittite Etymologies. In Florilegium Anatolicum, Mélanges offerts à Emmanuel Laroche. Pp. 297-304. Paris: Boccard.

Riemschneider, $\mathrm{M}$.

1954 Die Welt der Hethiter. Zurich: Fretz \& Wasmuth.

Smith, S.

1942 Review of A. Goetze, Kizzuwatna and the Problem of Hittite Geography. Journal of the Royal Asiatic Society 1942: 61-66.

1956 Uršu and Haššum. AnSt 6:35-43.

Soysal, O.

1987 KUB XXXI $4+K B o$ III 41 und 40 (Die Puhanu-Chronik). Zum Thronstreit Hattušiliš I. Hethitica 7:173-253.

Starke, F.

1977 Die Funktionen der dimensionalen Kasus und Adverbien im Althethitischen, StBoT 23. Wiesbaden: Harrassowitz.

Steinkeller, $\mathrm{P}$.

1987 Battering Rams and Siege Engines at Ebla. $N A B U$, item no. 27.

Von Brandenstein, C.-G.

1943 Hethitische Götter nach Bildbeschreibungen in Keilschrifttexten. Leipzig: J. C. Hinrich.

Von Soden, W.

1968 Review of CAD B, OLZ 63:457-59.

Wilhelm, G.

1982 Grundzüge der Geschichte und Kultur der Hurriter. Darmstadt: Wissenschaftliche Buchgesellschaft.

Yadin, $\mathrm{Y}$.

1963 The Art of Warfare in Biblical Lands. Vol. I. New York: McGraw-Hill. 